\title{
ANALISIS PERTANGGUNGJAWABAN KEUANGAN ORGANISASI NIRLABA DAN PENYUSUNAN LAPORAN KEUANGAN SESUAI DENGAN PSAK 45 DI MASJID AL-MUTTAQIN BEKASI
}

\author{
Yayang Novita Sari ${ }^{1)}$ \\ 1) Mahasiswa Program Studi Akuntansi FE UNKRIS \\ Hayuningtyas Pramesti Dewi ${ }^{2)}$ \\ 2) Dosen Program Studi Akuntansi FE UNKRIS \\ Alamat: Kampus UNKRIS, Jatiwaringin Jakarta Timur \\ Email: ethniz@gmail.com
}

\begin{abstract}
This research raises the issue of financial accountability for non-profit organizations. The object of the research was conducted at Al Muttaqin Mosque Jatibening Bekasi for the 2016-2017 reporting year. Data obtained from cash in and out cash recap, observation and interview. The results of the study were that the Al Muttaqin Mosque had not made a Financial Report in accordance with PSAK 45 so that the preparation of the Financial Statements in accordance with PSAK 45 was tried to be compiled in the study.
\end{abstract}

Keywords: Non-profit organizations, PSAK 45, financial report

\section{PENDAHULUAN}

Pada umumnya terdapat dua jenis organisasi yang menunjang perekonomian di Indonesia, yaitu organisasi bisnis yang berorientasi pada laba (profit motive) dan organisasi non bisnis yang tidak berorientasi pada laba. Organisasi non bisnis yang biasa disebut organisasi nirlaba merupakan organisasi yang didirikan untuk melayani masyarakat. Tidak ada kepemilikan dalam organisasi nirlaba karena pada dasarnya organisasi nirlaba adalah milik masyarakat. Masyarakat memerlukan organisasi nirlaba, begitu pula sebaliknya, karena hidup dan aktivitas organisasi nirlaba adalah dari masyarakat.

$$
\text { Dalam kaitannya dengan }
$$

pertanggungjawaban, organisasi nirlaba tidak berbeda dengan organisasi bisnis, yaitu organisasi nirlaba juga wajib membuat pertanggungjawaban kegiatannya. Masyarakat, yang dalam hal ini berperan sebagai sumber daya bagi organisasi nirlaba tentu memerlukan suatu bentuk pertanggungjawaban kegiatan dari organisasi nirlaba. Pertanggungjawaban organisasi dapat dibuat dalam bentuk
Laporan Keuangan. Laporan Keuangan untuk organisasi nirlaba dibuat melalui siklus akuntansi yang sama dengan organisasi bisnis lainnya, namun karena organisasi nirlaba itu bermacam-macam jenisnya dan setiap kegiatannya memiliki ciri khas yang unik, maka ada beberapa perbedaan terkait pelaporan keuangannya dengan organisasi bisnis.

Standar Akuntansi Keuangan Indonesia telah mengatur pelaporan keuangan organisasi nirlaba dalam satu standar, yaitu dalam Pernyataan Standar Akuntansi Keuangan (PSAK) no. 45. PSAK no. 45 dibuat khusus agar pelaporan keuangan organisasi nirlaba yang berbedabeda itu dapat disusun dengan standar yang sama agar mudah dipahami masyarakat. Namun seringkali kurangnya pengetahuan akan siklus akuntansi, PSAK no.45, dan penyusunan Laporan Keuangan membuat organisasi nirlaba belum membuat Laporan Keuangannya, atau telah membuat namun belum sesuai dengan Standar Akuntansi Keuangan yang mengaturnya. Seperti yang terjadi pada sebuah organisasi nirlaba yang bergerak di bidang keagamaan Masjid Al Muttaqin yang berlokasi di Jatibening Baru Bekasi. 
Masjid Al Muttaqin diabngun oleh masyarakat setempat yang selain diperuntukkan untuk tempat beribadah juga sebagai tempat warga berdiskusi untuk memajukan norma keagamaan dengan nyaman. Masjid Al Muttaqin sejak didirikan telah mengalami perkembangan yang pesat baik dari segi fasilitas maupun pelayanan beribadah. Namun dalam kaitannya dengan pertanggungjawaban keuangan, Masjid Al Muttaqin belum menyusun Laporan Keuangan yang sesuai dengan PSAK 45. Pertanggungjawaban keuangan yang dibuat oleh Masjid Al Muttaqin selama ini hanya sebatas penyajian pemasukan dan pengeluaran Kas. Adapun pencatatan Akuntansi juga belum mengelompokkan transaksi dalam akun-akun tertentu, kriteria pengelompokkan transaksi hanya berdasarkan kriteria yang dibuat oleh Masjid sendiri, bukan berdasarkan prinsip Akuntansi yang berlaku umum. Pencatatan transaksi yang dilakukan secara manual itu juga tidak rutin dilakukan sehingga sering terjadi selisih antara saldo tercatat dengan saldo yang sesungguhnya terjadi. Penelitian yang sejalan dengan penelitian ini pernah dilakukan oleh Diyani Ade Risky (2013) yang meneliti tentang penerapan PSAK no. 45 pada Yayasan Masjid Al Falah Surabaya dengan hasil penelitian bahwa yayasan belum mempunyai pedoman struktur organisasi yang memisahkan wewenang dan tanggung jawab dan pengakuan kerugian piutang diakui secara langsung. Dengan fenomena yang terjadi pada organisasi nirlaba maka dirumuskan permasalahan untuk dasar penelitian yaitu bagaimana proses pencatatan akuntansi di Masjid AlMuttaqin selama ini, dan bagaimana penyajian Laporan Keuangan yang sesuai PSAK no. 45 seharusnya pada Masjid AlMuttaqin untuk data penelitian pelaporan keuangan tahun 2016 dan 2017.

\section{Akuntansi}

Menurut Indra Mahardika (2017) "Akuntansi adalah sistem informasi yang menyediakan laporan untuk para pelaku kepentingan mengenai aktivitas ekonomi dan kondisi perusahaan". Sedangkan menurut Marshall B.Romny dan Paul John Steinbart (2014) "Akuntansi adalah proses identifikasi, pengumpulan dan penyimpanan data serta proses pengembangan, pengukuran dan komunikasi informasi”. Menurut H.Lili M. Sadeli (2015) "Akuntansi menyajikan informasi keuangan secara kuantitatif dan relevan kepada pihak-pihak yang berkepentingan dalam mengambil keputusan, baik untuk mengukur keberhasilan perusahaan maupun membuat rencana yang akan datang". Akuntansi dikatakan sebuah sistem untuk menghasilkan Laporan Keuangan yang dikerjakan melalui sebuah siklus yang dinamakan siklus akuntansi. Menurut Ani Rahmaniar dan Soegijanto (2016) "Siklus akuntansi adalah proses pengolahan data sejak terjadinya transaksi”.

\section{Akuntansi Organisasi Nirlaba}

Menurut PSAK No. 45 (2017)

"Organisasi Nirlaba adalah organisasi yang memperoleh dana dari sumbangan para anggota dan para penyumbang lainnya yang tidak mengharapkan imbalan apapun dari organisasi tersebut". Organisasi nirlaba merupakan perkumpulan atau individu yang bertujuan memberikan pelayanan dan jasa untuk masyarakat yang tidak mengharapkan suatu imbalan atau keuntungan dalam usahanya. Karakteristik Organisasi Nirlaba menurut IAI yang dikutip oleh Tantri Sofyana Putri (2015) adalah: 1) Sumber daya entitas berasal dari para penyumbang yang tidak mengharapkan pembayaran kembali atau manfaat ekonomi yang sebanding dengan jumlah sumber daya yang diberikan. 2) Menghasilkan barang/jasa tanpa tujuan untuk mencari laba, apabila menghasilkan laba pun maka

\section{LANDASAN TEORI}


jumlah tersebut tidak pernah dibagikan kepada pemilik. 3) Tidak ada kepemilikan seperti lazimnya organisasi bisnis.

\section{Laporan Keuangan Organisasi Nirlaba}

PSAK No. 45 (2017) menyatakan definisi Laporan Keuangan Nirlaba meliputi Laporan Posisi Keuangan pada akhir periode, Laporan Aktivitas, Laporan Arus Kas,untuk suatu periode pelaporan, dan Catatan Atas Laporan Keuangan Organisasi Nirlaba agar dapat lebih mudah dipahami, memiliki relevansi, dan memiliki daya banding yang tinggi.

\section{Laporan Posisi Keuangan Organisasi Nirlaba}

Laporan Posisi Keuangan entitas nirlaba menyajikan total Aset, Liabilitas dan Aset Neto. Tujuan laporan posisi keungan adalah untuk menyediakan informasi mengenai aset, liabilitas, dam aset neto serta informasi mengenai hubungan diantara unsur-unsur tersebut pada waktu tertentu. Informasi dalam laporan posisi keuangan yang digunakan bersama pengungkapan, dan informasi dalam laporan keuangan lain dapat membantu pemberi sumber daya yang tidak mengharapkan pembayaran kembali, anggota, kreditur, dan pihak lain untuk menilai Laporan entitas nirlaba untuk memberikan jasa secara berkelanjutan dan Likuiditas, fleksibilitas keuangan, kemampuan untuk memenuhi kewajibannya, dan kebutuhan pendanaan eksternal.

\section{Laporan Aktivitas}

Menurut PSAK No.45 (2017) laporan aktivitas adalah Laporan aktvitas mencakup entitas nirlaba secara keseluruhan dan menyajikan perubahan jumlah aset neto selama suatu periode. Perubahan aset neto dalam laporan aktivitas tercermin pada aset neto atau ekuitas dalam laporan keuangan. Tujuan utama laporan aktivitas adalah menyediakan informasi mengenai pengaruh transaksi dan peristiwa lain yang mengubah jumlah dan sifat aset neto; hubungan antara transaksi dan peristiwa lain; dan bagaimana menggunakan sumber daya dalam pelaksanaan berbagai program atau jasa. Informasi dalam laporan aktivitas, yang digunakan bersama dengan mengungkapkan informasi dalam laporan keuangan lainnya, dapat membantu pemberi sumber daya yang tidak mengharapkan pembayaran kembali, anggota kreditur, dan pihak lain untuk mengevaluasi kinerja dalam suatu periode. Laporan aktivitas menyajikan pendapatan sebagai aset neto tidak terikat, kecuali jika penggunaan dibatasi oleh pemberi sumber daya yang tidak mengharapkan pembayaran kembali, dan menyajikan beban sebagai pengurang aset neto tidak terikat. Sumber daya disajikan sebagai penambahan aset neto tidak terikat, terikat permanen, atau terikat temporer, tergantung pada ada tindakannya pembatasan. Dalam hal sumber daya terikat yang pembatasnnya tidak berlaku lagi dalam periode yang sama, dapat disajikan sebagai sumber daya yang tidak terikat sepanjang disajikan secara konsisten dan diungkapkan sebagai kebijakan akuntansi. Laporan aktivitas menyajikan keuntungan dan kerugian yang diakui dari investasi dan aset lain (atau liabilitas) sebagai penambahan atau pengurang aset neto tidak terikat, kecuali jika penggunaannya dibatasi.

\section{Laporan Arus Kas}

Menurut Dewi Utari (2014) "Laporan arus kas adalah perhitungan kas masuk dan kas keluar atas kegiatan operasi, investasi dan pembiayaan perusahaan". Menurut PSAK No.45 (2017) tujuan utama laporan arus kas adalah menyajikan informasi mengenai penerimaan dan pengeluaran kas dalam suatu periode. Organisasi nirlaba melaporkan arus kas sama halnya dengan organisasi bisnis.

\section{Catatan Atas Laporan Keuangan}


Catatan atas laporan keuangan adalah yang menjelaskan suatu unsur laporan keuangan dan menyajikan laporan posisi keuangan, laporan aktivitas, dan laporan arus kas, dalam penjelasan kebijakan-kebijakan akuntansi dan prosedur-prosedur yang diterapkan dalam organisasi yang bersangkutan sehingga memperoleh angka angka dan memberikan informasi yang mencakup hutang, kelangsungan usaha piutang, kewajiban kontijensi atau informasi kontekstual untuk menjelaskan angka-angka keuangan. Catatan laporan keuangan membantu menjelaskan perhitungan item tertentu dalam laporan keuangan serta memberikan penilain yang lebih komprehensif dari kondisi keuangan suatu entitas.

\section{METODE PENELITIAN}

Penelitian ini merupakan penelitian kualitatif dengan objek penelitian yaitu Masjid Al-Muttaqin Jatibening. Data berupa informasi keuangan diperoleh dengan cara Observasi, Wawancara dan mengumpulkan data dokumentasi objek. Adapun data dianalisa dengan deskriptif yang menggambarkan data yang diperoleh, berupa informasi keuangan, lalu membandingkannya dengan tolak ukur penelitian, yaitu PSAK 45.

\section{HASIL PENELITIAN DAN PEMBAHASAN}

\section{Hasil Penelitian}

Masjid Al-Muttaqin selama ini melakukan pencatatan transaksi-transaksi keuangannya hanya dalam berupa rekap kas pemasukan dan pengeluaran saja, tidak dikelompokkan dalam akun-akun yang dapat memperlihatkan sumber dana dan penggunaannya dan tidak melakukan pencatatan Aset Tetapnya. Berdasarkan hasil wawancara, Masjid Al-Muttaqin Jatibening belum membuat Laporan Posisi Keuangan, Laporan Aktivitas, Laporan Arus Kas dan Catatan Atas Laporan Keuangan yang diatur oleh PSAK 45 sebagai Laporan Keuangan untuk organisasi nirlaba.

\section{Pembahasan}

Penelitian ini mencoba untuk menyusun Laporan Keuangan untuk Masjid Al-Muttaqin periode 2016-2017 yang sesuai dengan PSAK 45. Penyusunan Laporan Keuangan menggunakan data informasi keuangan yang diperoleh dari Masjid Al-Muttaqin, kemudian disusun mengikuti siklus akuntansi. Berikut merupakan daftar akun yang dapat disusun dari informasi keuangan Masjid Al Muttaqin periode 2016-2017.

Tabel 1

Daftar Akun Masjid Al-Muttaqin Periode 2016-2017.

\begin{tabular}{cl|}
\hline $\begin{array}{c}\text { NO } \\
\text { AKUN }\end{array}$ & \multicolumn{1}{c|}{ NAMA AKUN } \\
\hline 101 & Kas \\
102 & Bank \\
103 & Perlengkapan \\
111 & Peralatan \\
112 & Tanah \\
113 & Bangunan \\
114 & Akumulasi Penyusutan Peralatan \\
115 & Akumulasi Penyusutan Bangunan \\
\hline Aset Neto Tidak Terikat: 301 \\
\hline Aset Neto Terikat Temporer: 302 \\
\hline Aset Neto Terikat Permanen: 303 \\
\hline
\end{tabular}




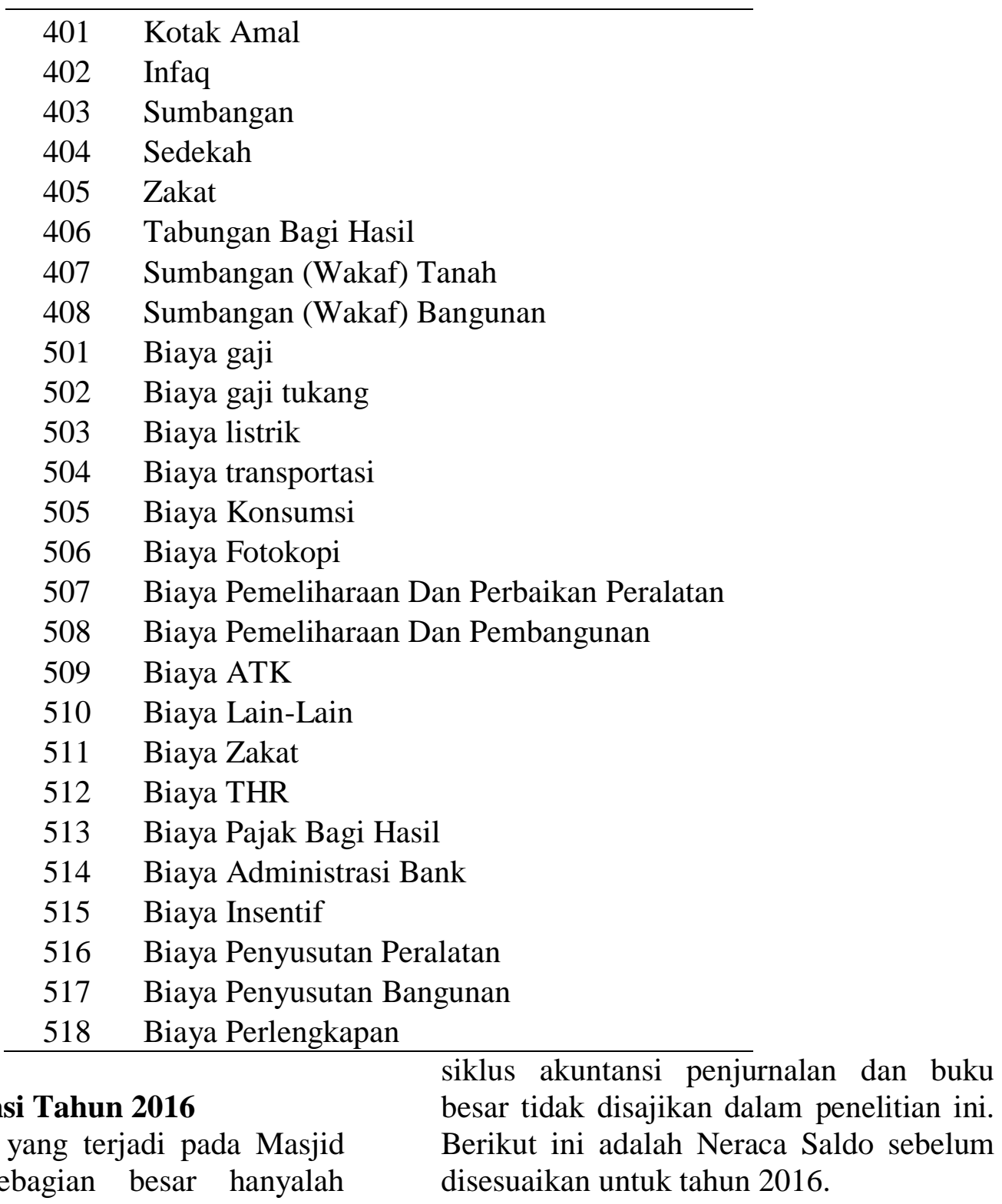

\section{Siklus Akuntansi Tahun 2016}

Transaksi yang terjadi pada Masjid Al-Muttaqin sebagian besar hanyalah mutasi Kas, dan untuk menyederhanakan,

\section{Tabel 2}

Masjid Al-Muttaqin

Neraca Saldo

Per 31 Desember 2016

\begin{tabular}{clrl}
\hline $\begin{array}{c}\text { No } \\
\text { Akun }\end{array}$ & \multicolumn{1}{c}{ Nama Akun } & Debit & Kredit \\
\hline 101 & Kas & 3.360 .850 & \\
102 & Bank & 50.495 .584 & \\
103 & Perlengkapan & 5.753 .800 & \\
111 & Peralatan & 327.198 .000 & \\
112 & Tanah & 52.850 .000 & \\
113 & Bangunan & 1.375 .000 .000 & \\
114 & Akumulasi Penyusutan Peralatan & & \\
115 & Akumulasi Penyusutan Bangunan & & \\
200 & Utang & & 38.112 .058 \\
301 & Aset Neto Tidak Terikat & & \\
302 & Aset Neto Terikat Temporer & &
\end{tabular}


303 Aset Neto Terikat Permanen

324.950 .000

401 Kotak Amal

108.865 .000

402 Infaq

11.678 .700

403 Sumbangan

102.049 .800

404 Sedekah

17.527.500

405 Zakat

406 Tabungan Bagi Hasil

474.769

407 Sumbangan (Wakaf) Tanah

52.850 .000

408 Sumbangan (Wakaf) Bangunan

1.375.000.000

501 Biaya gaji

65.600 .000

502 Biaya gaji tukang

14.833 .000

503 Biaya listrik

7.444 .000

504 Biaya transportasi

250.000

505 Biaya Konsumsi

5.746 .000

506 Biaya Fotokopi

694.350

507 Biaya Pemeliharaan Dan Perbaikan Peralatan

2.125 .000

508 Biaya Pemeliharaan Dan Pembangunan

110.462 .300

509 Biaya ATK

837.000

510 Biaya Lain-Lain

5.529 .000

511 Biaya Zakat

512 Biaya THR

2.500 .000

513 Biaya Pajak Bagi Hasil

101.943

77.000

514 Biaya Administrasi Bank

650.000

516 Biaya Penyusutan Peralatan

517 Biaya Penyusutan Bangunan

518 Biaya Perlengkapan

Total

Beberapa transaksi perlu dilakukan penyesuaian sebagai berikut:

Tabel 3

Masjid Al-Muttaqin

Jurnal Penyesuaian

31 Desember 2016

\begin{tabular}{|c|c|c|c|c|c|c|c|}
\hline \multirow[b]{2}{*}{ Tanggal } & \multirow[b]{2}{*}{ Keterangan } & Nomor & \multirow[b]{2}{*}{ Nama Akun } & \multirow{2}{*}{\multicolumn{2}{|c|}{ Debit }} & \multirow{2}{*}{\multicolumn{2}{|c|}{ Kredit }} \\
\hline & & Akun & & & & & \\
\hline \multirow[b]{2}{*}{31 des 2016} & \multirow[b]{2}{*}{ Penyusutan Tahun 2016} & 518 & Biaya Perlengkapan & & $5,453,800$ & & \\
\hline & & 103 & Perlengkapan & & & $\mathrm{Rp}$ & $5,453,800$ \\
\hline \multirow[b]{2}{*}{31 des 2016} & \multirow[b]{2}{*}{ Penyusutan Tahun 2016} & 516 & Biaya Penyusutan Peraalatan & $\mathrm{Rp}$ & $81,675,000$ & & \\
\hline & & 114 & Akumulasi Penyusutan Peralatan & & & $\mathrm{Rp}$ & $81,675,000$ \\
\hline \multirow[b]{2}{*}{ 31des2016 } & \multirow[b]{2}{*}{ Penyusutan Tahun 2016} & 517 & Biaya Penyusutan Bangunan & & $68,750,000$ & & \\
\hline & & 115 & Akumulasi Penyusutan Bangunan & & & $\mathrm{Rp}$ & $68,750,000$ \\
\hline \multicolumn{4}{|c|}{ Total AJP Des 2016} & $\mathrm{Rp}$ & $155,878,800$ & $\mathrm{Rp}$ & $155,878,800$ \\
\hline
\end{tabular}

Penyusunan Laporan Keuangan dilakukan setelah dilakukan proses penyesuaian.
Berikut ini merupakan Laporan Keuangan untuk tahun 2016. 


\section{Laporan Aktivitas}

Laporan aktivitas secara keseluruhan akan menyajikan perubahan Aset Bersih dalam satu periode. Laporan aktivitas menyajikan perubahan yang digolongkan dalam tidak terikat, terikat temporer, terikat permanen.

Tabel 4

\section{Masjid Al-Muttaqin}

Laporan Aktivitas

Untuk Periode Yang Berakhir tanggal 31 Desember 2016

\begin{tabular}{|c|c|c|c|c|c|c|c|}
\hline Nama Akun & \multicolumn{2}{|c|}{ Tidak Terikat } & Terikat Temporer & \multicolumn{2}{|c|}{ Terikat Permanen } & \multicolumn{2}{|r|}{ Jumlah } \\
\hline Aset Bersih & $\mathrm{Rp}$ & $38,112,058$ & & $\mathrm{Rp}$ & $324,950,000$ & $\mathrm{Rp}$ & $363,062,058$ \\
\hline Kotak Amal & $\mathrm{Rp}$ & $108,865,000$ & & & & $\mathrm{Rp}$ & $108,865,000$ \\
\hline Infaq & $\mathrm{Rp}$ & $11,678,700$ & & & & $\mathrm{Rp}$ & $11,678,700$ \\
\hline Sumbangan Pembangunan & & & & $\mathrm{Rp}$ & $102,049,800$ & $\mathrm{Rp}$ & $102,049,800$ \\
\hline Sedekah & $\mathrm{Rp}$ & $17,527,500$ & & & & $\mathrm{Rp}$ & $17,527,500$ \\
\hline Tabungan Bagi Hasil & $\mathrm{Rp}$ & 474,769 & & & & $\mathrm{Rp}$ & 474,769 \\
\hline Sumbangan (Wakaf) Tanah & & & & $\mathrm{Rp}$ & $52,850,000$ & $\mathrm{Rp}$ & $52,850,000$ \\
\hline Sumbangan (Wakaf) Bangunan & & & & $\mathrm{Rp}$ & $1,375,000,000$ & $\mathrm{Rp}$ & $1,375,000,000$ \\
\hline Jumlah Pendapatan & $\mathbf{R p}$ & $\mathbf{1 7 6 , 6 5 8 , 0 2 7}$ & $\mathbf{R p}$ & $\mathbf{R p}$ & $\mathbf{1 , 8 5 4 , 8 4 9 , 8 0 0}$ & $\mathbf{R p}$ & $\mathbf{2 , 0 3 1 , 5 0 7 , 8 2 7}$ \\
\hline Biaya Gaji & & & $65,600,000$ & & & $\mathrm{Rp}$ & $65,600,000$ \\
\hline Biaya Gaji Tukang & & & $14,833,000$ & & & $\mathrm{Rp}$ & $14,833,000$ \\
\hline Biaya Listrik & $\mathrm{Rp}$ & $7,444,000$ & & & & $\mathrm{Rp}$ & $7,444,000$ \\
\hline Biaya Transfortasi & $\mathrm{Rp}$ & 250,000 & & & & $\mathrm{Rp}$ & 250,000 \\
\hline Biaya Konsumsi & $\mathrm{Rp}$ & $5,746,000$ & & & & $\mathrm{Rp}$ & $5,746,000$ \\
\hline Biaya Fotokopi & $\mathrm{Rp}$ & 694,350 & & & & $\mathrm{Rp}$ & 694,350 \\
\hline Biaya Pemeliharaan Dan Perbaikan Peralatan & $\mathrm{Rp}$ & $2,125,000$ & & & & $\mathrm{Rp}$ & $2,125,000$ \\
\hline Biaya Pemeliharaan Dan Pembangunan & $\mathrm{Rp}$ & $110,462,300$ & & & & $\mathrm{Rp}$ & $110,462,300$ \\
\hline Biaya ATK & $\mathrm{Rp}$ & 837,000 & & & & $\mathrm{Rp}$ & 837,000 \\
\hline Biaya Lain-Lain & $\mathrm{Rp}$ & $5,529,000$ & & & & $\mathrm{Rp}$ & $5,529,000$ \\
\hline Biaya THR & $\mathrm{Rp}$ & $2,500,000$ & & & & $\mathrm{Rp}$ & $2,500,000$ \\
\hline Biaya Pajak Bagi Hasil & $\mathrm{Rp}$ & 101,943 & & & & $\mathrm{Rp}$ & 101,943 \\
\hline Biaya Administrasi Bank & $\mathrm{Rp}$ & 77,000 & & & & $\mathrm{Rp}$ & 77,000 \\
\hline Biaya Insentif & $\mathrm{Rp}$ & 650,000 & & & & $\mathrm{Rp}$ & 650,000 \\
\hline Biaya Penyusutan Peralatan & $\mathrm{Rp}$ & $81,675,000$ & & & & $\mathrm{Rp}$ & $81,675,000$ \\
\hline Biaya Penyusutan Bangunan & $\mathrm{Rp}$ & $68,750,000$ & & & & $\mathrm{Rp}$ & $68,750,000$ \\
\hline Biaya Perlengkapan & $\mathrm{Rp}$ & $5,453,800$ & & & & $\mathrm{Rp}$ & $5,453,800$ \\
\hline Jumlah Beban & $\mathbf{R p}$ & $292,295,393$ & $80,433,000$ & & & $\mathbf{R p}$ & $372,728,393$ \\
\hline Aset Bersih 2016 & $\mathbf{R p}$ & $(115,637,366)$ & $(80,433,000)$ & $\mathbf{R p}$ & $\mathbf{1 , 8 5 4 , 8 4 9 , 8 0 0}$ & $\mathbf{R p}$ & $1,658,779,434$ \\
\hline
\end{tabular}

\section{Laporan Arus Kas}

Laporan Arus Kas Masjid Al-Muttaqin disusun dengan metode langsung. Berikut ini adalah Laporan Arus Kas untuk tahun 2016. 


\section{Masjid Al-Muttaqin \\ Laporan Arus Kas}

Untuk Periode Yang Berakhir tanggal 31 Desember 2016

\begin{tabular}{|c|c|c|c|c|}
\hline \multicolumn{5}{|l|}{ Aliran Kas dari Aktivitas Ope rasi : } \\
\hline Kotak Amal & $\mathrm{Rp}$ & $108,865,000$ & & \\
\hline Infaq & $\mathrm{Rp}$ & $11,678,700$ & & \\
\hline Sumbangan Pembangunan & $\mathrm{Rp}$ & $102,049,800$ & & \\
\hline Sedekah & $\mathrm{Rp}$ & $17,527,500$ & & \\
\hline \multirow[t]{2}{*}{ Tabungan Bagi Hasil } & $\mathrm{Rp}$ & 474,769 & & \\
\hline & & JUMLAH & $\mathbf{R p}$ & $240,595,769$ \\
\hline \multicolumn{5}{|l|}{ Aliran Kas dari Aktivitas Investasi : } \\
\hline Pembelian Peralatan & $\mathrm{Rp}$ & $(2,248,000)$ & & \\
\hline \multirow[t]{2}{*}{ Pembelian Perlengkapan } & $\mathrm{Rp}$ & $(5,753,800)$ & & \\
\hline & & JUMLAH & $\mathbf{R p}$ & $(\mathbf{8 , 0 0 1 , 8 0 0 )}$ \\
\hline \multicolumn{5}{|l|}{ Aliran Kas dari Aktivitas Pendanaan : } \\
\hline Biaya Gaji & $\mathrm{Rp}$ & $(65,600,000)$ & & \\
\hline Biaya Gaji Tukang & $\mathrm{Rp}$ & $(14,833,000)$ & & \\
\hline Biaya Listrik & $\mathrm{Rp}$ & $(7,444,000)$ & & \\
\hline Biaya Transfortasi & $\mathrm{Rp}$ & $(250,000)$ & & \\
\hline Biaya Konsumsi & $\mathrm{Rp}$ & $(5,746,000)$ & & \\
\hline Biaya Fotokopi & $\mathrm{Rp}$ & $(694,350)$ & & \\
\hline Biaya Pemeliharaan Dan Perbaikan Peralatan & $\mathrm{Rp}$ & $(2,125,000)$ & & \\
\hline Biaya Pemeliharaan Dan Pembangunan & $\mathrm{Rp}$ & $(110,462,300)$ & & \\
\hline Biaya ATK & $\mathrm{Rp}$ & $(837,000)$ & & \\
\hline Biaya Lain-Lain & $\mathrm{Rp}$ & $(5,529,000)$ & & \\
\hline Biaya THR & $\mathrm{Rp}$ & $(2,500,000)$ & & \\
\hline Biaya Pajak Bagi Hasil & $\mathrm{Rp}$ & $(101,943)$ & & \\
\hline Biaya Administrasi Bank & $\mathrm{Rp}$ & $(77,000)$ & & \\
\hline Biaya Insentif & $\mathrm{Rp}$ & $(650,000)$ & & \\
\hline \multicolumn{3}{|r|}{ JUMLAH } & $\mathbf{R p}$ & $(216,849,593)$ \\
\hline \multicolumn{3}{|l|}{ TOTAL } & $\mathbf{R p}$ & $15,744,376$ \\
\hline \multicolumn{3}{|c|}{ Kas dan Setara Kas pada Akhir Tahun 2015} & $\mathbf{R p}$ & $38,112,058$ \\
\hline \multicolumn{3}{|c|}{ Kas dan Setara Kas pada Akhir Tahun 2016} & $\mathbf{R p}$ & $53,856,434$ \\
\hline
\end{tabular}

Untuk Laporan Posisi Keuangan tahun 2016 akan disajikan bersama dengan Laporan Posisi Keuangan tahun 2017.

Siklus Akuntansi Tahun 2017
Berikut akan dibahas penyusunan Laporan Keuangan Masjid Al-Muttaqin untuk tahun 2017. Neraca Saldo tahun 2017 sebelum disesuaikan disajikan pada tabel dibawah ini

Tabel 6

Masjid Al-Muttaqin

Neraca Saldo

Per 31 Desember 2017

\begin{tabular}{clrr}
\hline $\begin{array}{c}\text { No } \\
\text { Akun }\end{array}$ & \multicolumn{1}{c}{ Nama Akun } & Debit & Kredit \\
\hline 101 & Kas & 6.198 .310 & \\
102 & Bank & 62.236 .405 & \\
103 & Perlengkapan & 3.294 .700 & \\
111 & Peralatan & 328.207 .000 & \\
112 & Tanah & 52.850 .000 & \\
113 & Bangunan & 1.375 .000 .000 & \\
114 & Akumulasi Penyusutan Peralatan & & 81.675 .000 \\
115 & Akumulasi Penyusutan Bangunan & & 68.750 .000
\end{tabular}


$200 \quad$ Utang

301 Aset Neto Tidak Terikat

230.554 .434

302 Aset Neto Terikat Temporer

303 Aset Neto Terikat Permanen

401 Kotak Amal

142.501 .900

402 Infaq

10.918 .000

403 Sumbangan

66.485 .000

404 Sedekah

15.992 .000

405 Zakat

39.895 .000

406 Tabungan Bagi Hasil

269.272

407 Sumbangan (Wakaf) Tanah

52.850 .000

408 Sumbangan (Wakaf) Bangunan

1.375 .000 .000

501 Biaya gaji

78.244 .000

502 Biaya gaji tukang

64.376 .000

503 Biaya listrik

9.641 .000

504 Biaya transportasi

505 Biaya Konsumsi

5.064 .600

506 Biaya Fotokopi

677.540

507 Biaya Pemeliharaan Dan Perbaikan Peralatan

2.025 .000

508 Biaya Pemeliharaan Dan Pembangunan

59.779 .700

509 Biaya ATK

962.500

510 Biaya Lain-Lain

1.675 .000

511 Biaya Zakat

32.096 .000

512 Biaya THR

2.500 .000

513 Biaya Pajak Bagi Hasil

53.851

514 Biaya Administrasi Bank

84.000

515 Biaya Insentif

516 Biaya Penyusutan Peralatan

517 Biaya Penyusutan Bangunan

518 Biaya Perlengkapan

Total

2.084.965.606

2.084.965.606

Transaksi yang perlu disesuaikan pada akhir tahun 2017 adalah sebagai berikut:

Tabel 7

Masjid Al-Muttaqin

Jurnal Penyesuaian

31 Desember 2017

\begin{tabular}{|c|c|c|c|c|c|c|c|}
\hline \multirow[b]{2}{*}{ Tanggal } & \multirow[b]{2}{*}{ Keterangan } & Nomor & \multirow[b]{2}{*}{ Nama Akun } & \multirow{2}{*}{\multicolumn{2}{|c|}{ Debit }} & \multirow{2}{*}{\multicolumn{2}{|c|}{ Kredit }} \\
\hline & & Akun & & & & & \\
\hline \multirow[b]{2}{*}{31 des 2017} & \multirow[b]{2}{*}{ Penyusutan Tahun 2017} & 518 & Biaya Perlengkapan & & $3,144,700$ & & \\
\hline & & 103 & Perlengkapan & & & $\mathrm{Rp}$ & $3,144,700$ \\
\hline \multirow[b]{2}{*}{ 31des2017 } & \multirow[b]{2}{*}{ Penyusutan Tahun 2017} & 516 & Biaya Penyusutan Peraalatan & & $81,675,000$ & & \\
\hline & & 114 & Akumulasi Penyusutan Peralatan & & & $\mathrm{Rp}$ & $81,675,000$ \\
\hline \multirow[b]{2}{*}{ 31des2017 } & \multirow[b]{2}{*}{ Penyusutan Tahun 2017} & 517 & Biaya Penyutan Bangunan & & $68,750,000$ & & \\
\hline & & 115 & Akumulasi Penyusutan Bangunan & & & $\mathrm{Rp}$ & $68,750,000$ \\
\hline \multicolumn{4}{|c|}{ Setelah proses penyesuatidaAJP dissalikan } & $\mathrm{Rp}$ & $153,569,700$ & $\mathrm{Rp}$ & $153,569,700$ \\
\hline
\end{tabular}

Laporan Keuangan untuk periode tahun

2017 adalah sebagai berikut: 
Laporan Aktivitas Tahun 2017

Tabel 8

Masjid Al-Muttaqin

Laporan Aktivitas

Untuk Periode Yang Berakhir Tanggal 31 Desember 2017

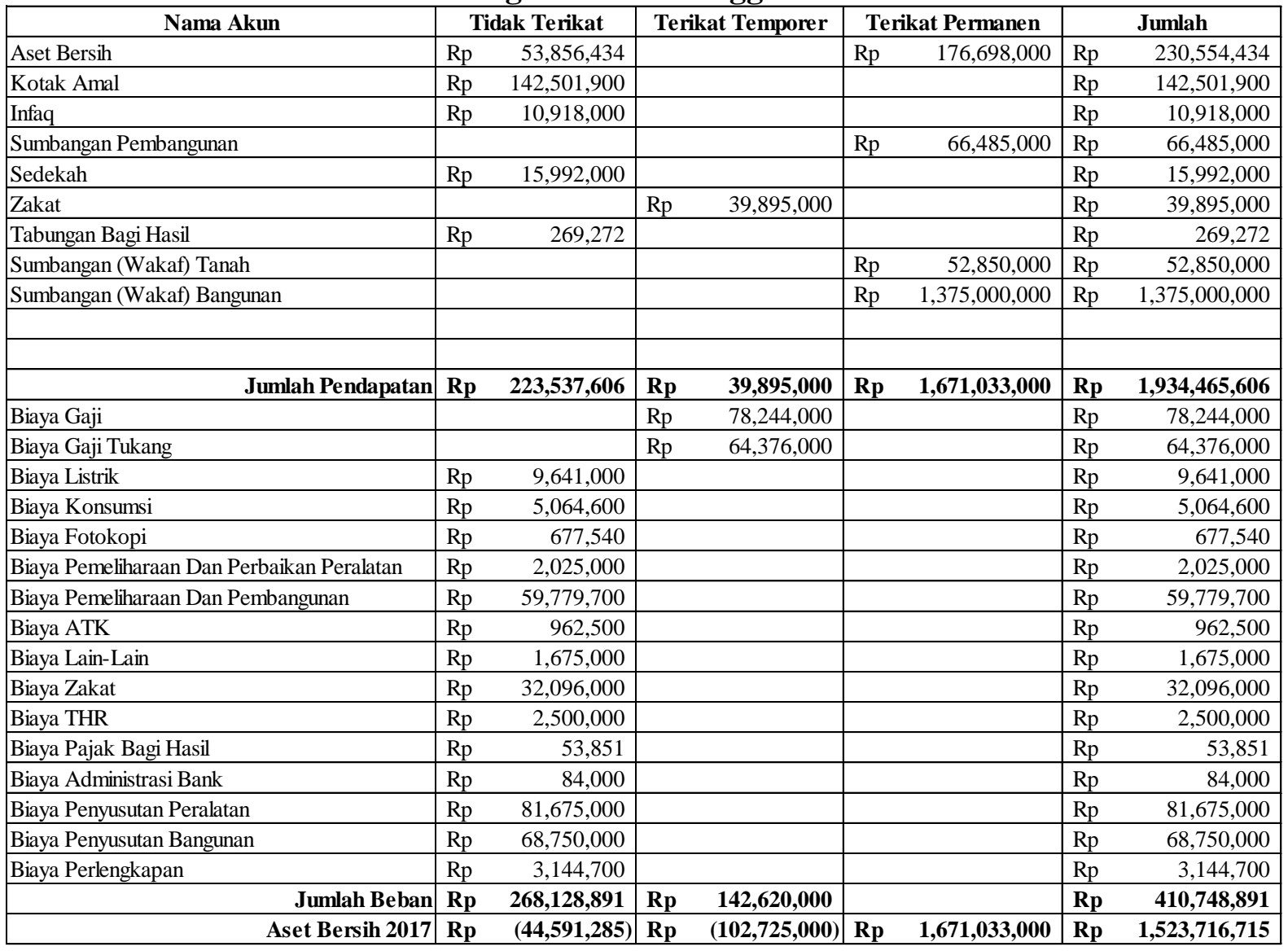


Tabel 9

Masjid Al-Muttaqin

Laporan Arus Kas

Untuk Periode Yang Berakhir tanggal 31 Desember 2017

\begin{tabular}{|c|c|c|c|}
\hline \multicolumn{4}{|l|}{ Aliran Kas dari Aktivitas Operasi : } \\
\hline Kotak Amal & $\mathrm{Rp} \quad 142,501,900$ & & \\
\hline Infaq & $10,918,000$ & & \\
\hline Sumbangan & $66,485,000$ & & \\
\hline Sedekah & $15,992,000$ & & \\
\hline Zakat & $39,895,000$ & & \\
\hline \multirow[t]{2}{*}{ Tabungan Bagi Hasil } & 269,272 & & \\
\hline & JUMLAH & $\mathbf{R p}$ & $276,061,172$ \\
\hline \multicolumn{4}{|l|}{ Aliran Kas dari Aktivitas Investasi : } \\
\hline Pembelian Peralatan & $(1,009,000)$ & & \\
\hline \multirow[t]{2}{*}{ Pembelian Perlengkapan } & $(3,294,700)$ & & \\
\hline & JUMLAH & $\mathbf{R p}$ & $(4,303,700)$ \\
\hline \multicolumn{4}{|l|}{ Aliran Kas dari Aktivitas Pendanaan : } \\
\hline Biaya Gaji & $(78,244,000)$ & & \\
\hline Biaya Gaji Tukang & $\operatorname{Rp} \quad(64,376,000)$ & & \\
\hline Biaya Listrik & $(9,641,000)$ & & \\
\hline Biaya Konsumsi & $(5,064,600)$ & & \\
\hline Biaya Fotokopi & $(677,540)$ & & \\
\hline Biaya Pemeliharaan Dan Perbaikan Peralatan & $(2,025,000)$ & & \\
\hline Biaya Pemeliharaan Dan Pembangunan & $(59,779,700)$ & & \\
\hline Biaya ATK & $(962,500)$ & & \\
\hline Biaya Lain-Lain & $(1,675,000)$ & & \\
\hline Biaya Zakat & $(32,096,000)$ & & \\
\hline Biaya THR & $(2,500,000)$ & & \\
\hline Biaya Pajak Bagi Hasil & $(53,851)$ & & \\
\hline Biaya Administrasi Bank & $(84,000)$ & & \\
\hline \multicolumn{2}{|r|}{ JUMLAH } & $\mathbf{R p}$ & $(257,179,191)$ \\
\hline \multicolumn{2}{|r|}{ TOTAL } & $\mathbf{R p}$ & $14,578,281$ \\
\hline \multicolumn{2}{|c|}{ Kas dan Setara Kas pada Akhir Tahun 2016} & $\mathrm{Rp}$ & $53,856,434$ \\
\hline \multicolumn{2}{|c|}{ Kas dan Setara Kas pada Akhir Tahun 2017} & $\mathbf{R p}$ & $68,434,715$ \\
\hline
\end{tabular}


Berikut ini disajikan Laporan Posisi Keuangan per 31 Desember 2016 dan 31 Desember 2017

Tabel 10

Masjid Al-Muttaqin

Laporan Posisi Keuangan

Per 31 Desember 2016 dan 31 Desember 2017

\begin{tabular}{|c|c|c|c|c|}
\hline \multirow{2}{*}{\begin{tabular}{|l|} 
Aset : \\
Kas dan Setara Kas \\
\end{tabular}} & \multicolumn{2}{|c|}{ Tahun 2016} & \multicolumn{2}{|c|}{ Tahun 2017} \\
\hline & $\mathrm{Rp}$ & $53,856,434$ & $\mathrm{Rp}$ & $68,434,715$ \\
\hline Perlengkapan & $\mathrm{Rp}$ & 300,000 & $\mathrm{Rp}$ & 150,000 \\
\hline Peralatan & $\mathrm{Rp}$ & $327,198,000$ & $\mathrm{Rp}$ & $328,207,000$ \\
\hline Akm, Penyusutan Peralatan & $\mathrm{Rp}$ & $(81,675,000)$ & $\mathrm{Rp}$ & $(163,350,000)$ \\
\hline Tanah & $\mathrm{Rp}$ & $52,850,000$ & $\mathrm{Rp}$ & $52,850,000$ \\
\hline Bangunan & $\mathrm{Rp}$ & $1,375,000,000$ & $\mathrm{Rp}$ & $1,375,000,000$ \\
\hline Akm. Penyusutan Bangunan & $\mathrm{Rp}$ & $(68,750,000)$ & $\mathrm{Rp}$ & $(137,500,000)$ \\
\hline Total Aset & $\mathbf{R p}$ & $1,658,779,434$ & $\mathbf{R p}$ & $1,523,791,715$ \\
\hline \multicolumn{5}{|l|}{ Kewajiban dan Aset Bersih : } \\
\hline Hutang & $\mathrm{Rp}$ & - & $\mathrm{Rp}$ & - \\
\hline Jumlah Hutang & $\mathrm{Rp}$ & - & $\mathrm{Rp}$ & - \\
\hline \multicolumn{5}{|l|}{ Aset Bersih : } \\
\hline Tidak Terikat (Catatan B) & $\mathrm{Rp}$ & $(115,637,366)$ & $\mathrm{Rp}$ & $(195,016,285)$ \\
\hline Terikat Temporer (Catatan C) & $\mathrm{Rp}$ & $(80,433,000)$ & $\mathrm{Rp}$ & $(102,725,000)$ \\
\hline Terikat Permanen (Catatan D) & $\mathrm{Rp}$ & $1,854,849,800$ & $\mathrm{Rp}$ & $1,821,533,000$ \\
\hline Total Kewajiban dan Aset Bersih & $\mathbf{R p}$ & $1,658,779,434$ & $\mathbf{R p}$ & $\mathbf{1 , 5 2 3 , 7 9 1 , 7 1 5}$ \\
\hline
\end{tabular}

\section{Catatan Atas Laporan Keuangan}

Tahun 2016

\section{Catatan A}

Tanah Masjid Al-Muttaqin telah di wakafkan tanah oleh pihak Developer (PT. Maena Putra Satya) menyediakan 4 (Empat) lokasi fasilitas umum (Fasum) satu diantaranya adalah sebidang tanah seluas \pm 1057 M2 seharga tanah Rp 52,850,000, tanah tersebut di berikan pada tahun 1982 dan di kelolah oleh masyarakan. Bangunan Masjid AlMuttaqin didirikan pada Mei 1989 Masjid Al-Muttaqin secara resmi telah digunakan oleh masyarakat yang di berih nama "Masjid Al-Muttaqin". Maret 2010 Dewan Kemakmuran Masjid (DKM) Al-Muttaqin melakukan Rehabilitas pelaksanaan dimulai pada tanggal 17 Januari 2011 dan
Pembangunannya selesai pada tanggal 9 Juli 2013. Dengan Luas bangunan \pm 550

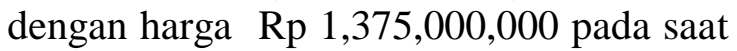
2013

\section{Catatan B}

Catatan B membahas tentang aktivitas bersih tidak terikat, data dikelompokkan dari infaq, sedekah dan kotak amal serta pengeluaran yang digunakan untuk operasional Masjid Al-Muttaqin, berikut aktivitas bersih tidak terikat: 


Aset Neto Tidak Terikat
Kotak Amal
Infaq
Sedekah
Tabungan Bagi Hasil

Biaya Listrik

Biaya Transfortasi

Biaya Konsumsi

Biaya Fotokopi

Biaya Pemeliharaan Dan Perbaikan Peralatan

Biaya Pemeliharaan Dan Pembangunan

Biaya ATK

Biaya Lain-Lain

Biaya THR

Biaya Pajak Bagi Hasil

Biaya Administrasi Bank

Biaya Insentif

Biaya Penyusutan Peralatan

Biaya Penyusutan Bangunan

Biaya Perlengkapan

$$
\begin{array}{rr}
\text { Rp } & 38,112,058 \\
\text { Rp } & 108,865,000 \\
\text { Rp } & 11,678,700 \\
\text { Rp } & 17,527,500 \\
\text { Rp } & 474,769
\end{array}
$$

Jumlah

Rp $\quad 7,444,000$

$\mathrm{Rp} \quad 250,000$

$\mathrm{Rp} \quad 5,746,000$

$\mathrm{Rp} \quad 694,350$

$\mathrm{Rp} \quad 2,125,000$

Rp $\quad 110,462,300$

Rp $\quad 837,000$

Rp $\quad 5,529,000$

$\mathrm{Rp} \quad 2,500,000$

$\mathrm{Rp} \quad 101,943$

Rp $\quad 77,000$

Rp $\quad 650,000$

Rp $\quad 81,675,000$

Rp $\quad 68,750,000$

$\mathrm{Rp} \quad 5,453,800$

\section{Jumlah Beban}

Aset bersih 2016

Catatan C

Aktivitas bersih terikat temporer berasal dari donatur untuk diberikan kepada

Rp 292,295,393

Rp $(\mathbf{1 1 5 , 6 3 7 , 3 6 6 )}$

Rp 176,658,027

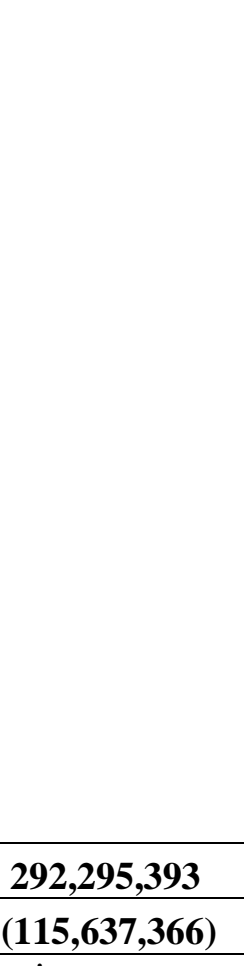

masjid dengan operasional rutin yang dilakukan oleh Masjid Al-Muttaqin

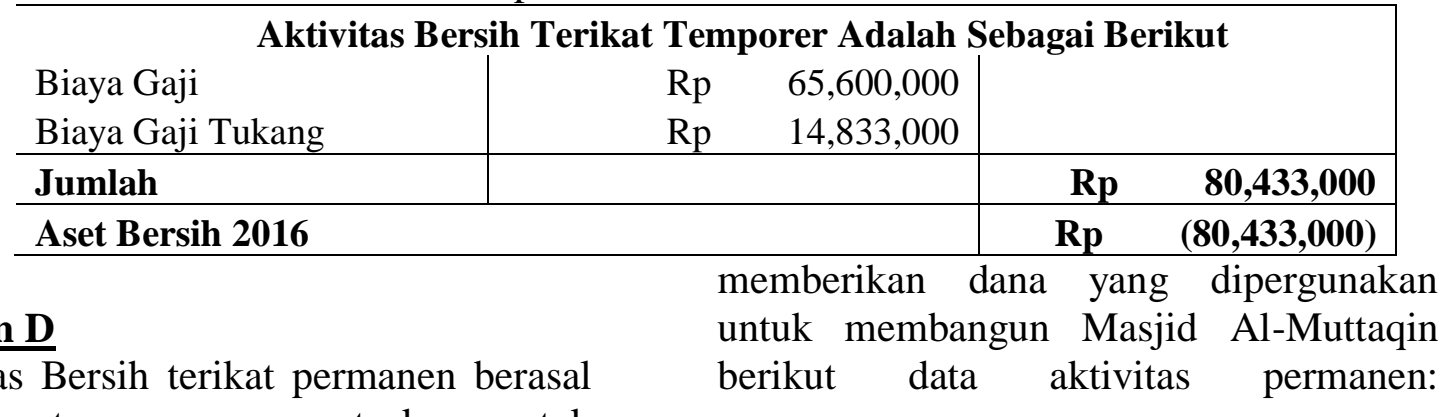

\section{Catatan D}

Aktivitas Bersih terikat permanen berasal dari donatur yang memutuskan untuk

\begin{tabular}{lrrrr}
\hline \multicolumn{5}{c}{ Aktivitas Bersih Terikat Permanen Adalah Sebagai Berikut (Dalam Rupiah) } \\
Aset Bersih Terikat Permanen & Rp & 324.950 .000 & & \\
Sumbangan Pembangunan & Rp & $102,049,800$ & & \\
Sumbangan (Wakaf) Tanah & Rp & $52,850,000$ & & \\
Sumbangan (Wakaf) Bangunan & Rp & $1,375,000,000$ & & \\
\hline Aset Bersih 2016 & & & Rp & $\mathbf{1 . 8 5 4 . 8 4 9 . 8 0 0}$ \\
\hline
\end{tabular}

\section{Catatan E}


Adalah daftar peralatan yang terdapat di Masjid Al-Muttaqin

\begin{tabular}{|rlcrrr}
\hline No & \multicolumn{1}{c}{ Keterangan } & Unit & Tahun & \multicolumn{1}{c}{ Nilai } & \multicolumn{1}{c}{$\begin{array}{c}\text { Penyusutan } \\
\text { Pertahun }\end{array}$} \\
\hline 1 & AC & 12 & 2014 & $34,200,000$ & $8,550,000$ \\
2 & Kipas Angin & 10 & 2014 & $1,760,000$ & 440,000 \\
3 & Kipas Angin Blower & 2 & 2014 & 560,000 & 140,000 \\
4 & Keranda & 1 & 2014 & $3,500,000$ & 875,000 \\
5 & Tempat Pemandian Jenazah & 1 & 2014 & $3,000,000$ & 750,000 \\
6 & Laptop & 1 & 2014 & $4,500,000$ & $1,125,000$ \\
7 & Printer & 1 & 2014 & $1,775,000$ & 443,750 \\
8 & Meja Lipat & 3 & 2014 & 225,000 & 56,250 \\
9 & Mimbar & 2 & 2014 & $4,000,000$ & $1,000,000$ \\
10 & Karpet Sajadah & 36 & 2014 & $126,000,000$ & $31,500,000$ \\
11 & Sound System & 1 & 2014 & $74,400,000$ & $18,600,000$ \\
12 & Al-Qur'an & 10 & 2014 & 80,000 & 20,000 \\
13 & Italase Kecil & 1 & 2014 & 300,000 & 75,000 \\
14 & Lemari Mukena & 1 & 2014 & 300,000 & 75,000 \\
15 & Meja Printer & 1 & 2014 & 400,000 & 100,000 \\
16 & Kursi Lipat & 5 & 2014 & 750,000 & 187,500 \\
17 & Lampu Utama & 2 & 2014 & $58,000,000$ & $14,500,000$ \\
18 & Penyedot Debu & 1 & 2014 & $11,200,000$ & $2,800,000$ \\
\hline & Total & & & $\mathbf{3 2 4 , 9 5 0 , 0 0 0}$ & $\mathbf{8 1 , 2 3 7 , 5 0 0}$ \\
\hline
\end{tabular}

\section{Tahun 2017}

\section{Catatan A}

Masjid Al-Muttaqin pada tahun 2017 yang dimiliki Masjid Al-Muttaqin pada memiliki tanah yang sama pada tahun tahun 2017

2016 dan begitupun dengan Bangunan

\section{Catatan B}

Data tentang aktivitas bersih tidak terikat

\section{Aktivitas Bersih Tidak Terikat Adalah Sebagai Berikut}

Saldo Awal

Kotak Amal

Infaq

Sedekah

Tabungan Bagi Hasil

Biaya Listrik

Biaya Konsumsi

Biaya Fotokopi

Biaya Pemeliharaan Dan Perbaikan Peralatan

Biaya Pemeliharaan Dan Pembangunan

Jumlah

$$
\begin{array}{lr}
\text { Rp } & 53,856,434 \\
\text { Rp } & 142,501,900 \\
\text { Rp } & 10,918,000 \\
\text { Rp } & 15,992,000 \\
\text { Rp } & 269,272
\end{array}
$$

Rp

$223,537,606$

$$
\begin{array}{lr}
\text { Rp } & 9,641,000 \\
\text { Rp } & 5,064,600 \\
\text { Rp } & 677,540 \\
\text { Rp } & 2,025,000 \\
\text { Rp } & 59,779,700
\end{array}
$$




\begin{tabular}{llr} 
Biaya ATK & $\mathrm{Rp}$ & 962,500 \\
Biaya Lain-Lain & $\mathrm{Rp}$ & $1,675,000$ \\
Biaya Zakat & $\mathrm{Rp}$ & $32,096,000$ \\
Biaya THR & $\mathrm{Rp}$ & $2,500,000$ \\
Biaya Pajak Bagi Hasil & $\mathrm{Rp}$ & 53,851 \\
Biaya Administrasi Bank & $\mathrm{Rp}$ & 84,000 \\
Biaya Penyusutan Peralatan & $\mathrm{Rp}$ & $81,675,000$ \\
Biaya Penyusutan Bangunan & $\mathrm{Rp}$ & $68,750,000$ \\
Biaya Perlengkapan & $\mathrm{Rp}$ & $3,144,700$ \\
\hline
\end{tabular}

\begin{tabular}{lll}
\hline Jumlah Beban & Rp & $\mathbf{2 6 8 , 1 2 8 , 8 9 1}$ \\
\hline Aset Bersih 2017 & Rp & $(44,591,285)$ \\
\hline
\end{tabular}

\section{Catatan C}

Aktivitas Bersih Terikat Temporer Adalah Sebagai Berikut

\begin{tabular}{lcrrr} 
Zakat & Rp & $39,895,000$ & & \\
Jumlah & & & Rp & $\mathbf{3 9 , 8 9 5 , 0 0 0}$ \\
Biaya Gaji & Rp & $78,244,000$ & & \\
Biaya Gaji Tukang & Rp & $64,376,000$ & & \\
\hline Jumlah & & & Rp & $\mathbf{1 4 2 , 6 2 0 , 0 0 0}$ \\
\hline Aset Bersih 2017 & & & Rp & $\mathbf{( 1 0 2 , 7 2 5 , 0 0 0 )}$ \\
\hline
\end{tabular}

\section{Catatan D}

\begin{tabular}{lcc}
\multicolumn{4}{l}{ Aktivitas Bersih Terikat Permanen Adalah Sebagai Berikut } \\
Aset Bersih Terikat Permanen & Rp & $176,698,000$ \\
Sumbangan Pembangunan & Rp & $66,485,000$ \\
Sumbangan (Wakaf) Tanah & Rp & $52,850,000$ \\
Sumbangan (Wakaf) Bangunan & Rp & $1,375,000,000$
\end{tabular}

Aset Bersih 2017

Rp $1,671,033,000$

\section{Catatan E}

Sama dengan Tahun 2016.

\section{SIMPULAN DAN SARAN}

\section{Simpulan}

Simpulan yang dapat ditarik dari penelitian ini adalah bahwa Organisasi Nirlaba Masjid Al-Muttaqin telah berusaha untuk membuat pertanggungjawaban keuangannya dengan membuat rekap kas masuk dan kas keluar untuk para donatur, namun pertanggungjawaban keuangannya belum sesuai dengan Standar Akuntansi yang berlaku untuk organisasi nirlaba, yaitu PSAK 45, dimana Masjid Al-
Muttaqin belum membuat Laporan Keuangan yang diatur oleh PSAK 45.

\section{Saran}

Berdasarkan simpulan dari hasil penelitian, maka disarankan kepada Masjid Al-Muttaqin untuk memberikan pelatihan kepada para pengurusnya untuk pengetahuan tentang pelaporan keuangan nirlaba yang terstandar oleh Ikatan Akuntan Indonesia, yaitu PSAK 45. 
Dengan pelaporan keuangan yang terstandar maka penyajian informasi aktivitas yang dilakukan oleh Masjid dapat lebih mudah memberikan informasi kepada masyarakat, sehingga dapat lebih

\section{DAFTAR PUSTAKA}

Abdul Halim,Muhammad Syam, 2014, Teori Konsep Dan Aplikasi Akuntansi Sector Public, Jakarta: Salemba Empat.

Ani Rahmaniar, Soegijanto, 2016, Pengantar Akuntansi Dasar 1, Penerbit In Media.

Baldric Siregar, 2017, Akuntansi Sector Public (Akuntansi Keuangan Pemerintah Daerah Berbasis Akrual), Edisi 2, Yogyakarta: UPP STIM YKPN.

Budianor, 2016, Masjid Sebagai Pusat Dakwa Islam (Studi Tentang Aktivitas Dakwa Islam Di Masdid Raya Darussalam Palangka Raya), Skripsi Institute Agama Islam Negeri Palangka Raya.

Dewi Utari, 2014, Manajemen Keuangan, Edisi Revisi, Mitra Wacana Media.

Diyani Ade Risky, Yazid Yud Padomo, 2013, Analisis Penerapan PSAK No.45 Pada Yayasan Masjid Al-Falah Kota Surabaya, Jurnal Ilmu \& Riset Akuntansi Vol.2 No.7, Sekolah Tinggi Ilmu Ekonomi Indonesia (STIESIA) Surabaya.

H. Lili M. Sadeli, 2015, Dasar-Dasar Akuntansi, Jakarta : Bumi Askara

Hery, 2015, Akuntansi Dasar 1 Dan 2, Jakarta: PT Grasindo. mempercayai aktivitas Masjid dalam memberikan pelayanan kepada mereka.

Hery, 2016, Analisis Laporan Keuangan Intergrated And Comprehensive Edition, Jakarta: PT Grasindo.

Hery, 2017, Praktis Menyusun Laporan Keuangan, Jakarta: PT Grasindo.

Ikatan Akuntan Indonesia (IAI), 2017, Standar Akuntansi Keuangan, Jakarta: Salemba Empat.

Indra Mahardika Putra, 2017, Pengantar Akuntansi, Cetakan 1, Yogyakart: Quadrant.

Marja Sinurat, 2018, Akuntansi Keuangan Daerah, Cetakan 1, Ghalia Indonesia.

Marshall B Romney, \& Paul Jhon Steinbart, 2014, Sistem Informasi Akuntansi, Jakarta : Salemba Empat.

Moh.Mahsun, 2016, Akuntansi Sector Public, Edisi 3, Cetakan 6, BPFEYogyakarta.

Rahman Pura, 2013, Pengantar Akuntansi 1 Pendekatan Siklus Akuntansi, Erlangga.

Rozalinda, 2016, Ekonomi Islam: Teori Dan Aplikasi Pada Aktivitas Ekonomi, Cetakan Ke-3, Jakarta: Rajawali Pers

V.Wiratna, 2015, Akuntansi Sector Public, Yogyakarta; Pustaka Baru Press.

V.Wiratna, 2016, Pengantar Akuntansi, Yogyakarta: Pustaka Baru Press. 
